\title{
Detrusor underactivity
}

Citation for published version (APA):

Rademakers, K. L. J. (2017). Detrusor underactivity: from theory to clinical assessment. [Doctoral Thesis, Maastricht University]. Maastricht University. https://doi.org/10.26481/dis.20171026kr

Document status and date:

Published: 01/01/2017

DOI:

10.26481/dis.20171026kr

Document Version:

Publisher's PDF, also known as Version of record

\section{Please check the document version of this publication:}

- A submitted manuscript is the version of the article upon submission and before peer-review. There can be important differences between the submitted version and the official published version of record.

People interested in the research are advised to contact the author for the final version of the publication, or visit the DOI to the publisher's website.

- The final author version and the galley proof are versions of the publication after peer review.

- The final published version features the final layout of the paper including the volume, issue and page numbers.

Link to publication

\footnotetext{
General rights rights.

- You may freely distribute the URL identifying the publication in the public portal. please follow below link for the End User Agreement:

www.umlib.nl/taverne-license

Take down policy

If you believe that this document breaches copyright please contact us at:

repository@maastrichtuniversity.nl

providing details and we will investigate your claim.
}

Copyright and moral rights for the publications made accessible in the public portal are retained by the authors and/or other copyright owners and it is a condition of accessing publications that users recognise and abide by the legal requirements associated with these

- Users may download and print one copy of any publication from the public portal for the purpose of private study or research.

- You may not further distribute the material or use it for any profit-making activity or commercial gain

If the publication is distributed under the terms of Article $25 \mathrm{fa}$ of the Dutch Copyright Act, indicated by the "Taverne" license above, 


\section{Summary}

Detrusor Underactivity (DU) is a functional urological entity in disguise without consensus on diagnostic evaluation or established treatment. Symtoms related to impaired bladder emptying caused by either DU, bladder outlet obstruction (BOO) or both are a frequent reason for outpatient consultation. However, for a long time research has not been focused on the background related to these symptoms. It is only at the International Consultation on Incontinence research society (ICI-RS) meeting of 2011 that the topic regained interest. The content of this thesis has kickstarted research in the field of DU, with specific attention towards pathophysiology of voiding function, measurement techniques for DU, and therapeutic options and margins.

Chapter 1 discusses the role of alternative pressure-flow measurement tools to differentiate various lower urinary tract dysfunctions. In this chapter specific attention is directed towards the role of ambulatory urodynamic monitoring (AUM) in impaired bladder emptying. Contractile dysfunction of the detrusor may vary from DU/hypocontractility to an acontractile bladder. AUM is shown to better differentiate between patients with bladder acontractility and hypocontractility. This knowledge is necessary in treatment of DU patients, for example with sacral neuromodulation (SNM). Patients with AUM based acontractility may be prone to a significantly reduced SNM treatment outcome compared to AUM based hypocontractile patients.

Chapter 2 is the first of three publications highlighting the relationship between BOO and detrusor contractile function in men during voiding. In the urological practice both bladder contractility index $(\mathrm{BCl})$ and maximum Watts factor $\left(\mathrm{W}_{\max }\right)$ are used to calculate detrusor strength in men with lower urinary tract symptoms (LUTS) using fixed threshold values for all men. This retrospective cohort study shows that detrusor contraction power parameters - $\mathrm{BCl}$ and $\mathrm{W}_{\max }$ - continuously increase with rising $\mathrm{BOO}$ grade. According to these results, it has been shown impossible to determine a single threshold value for detrusor contraction power to diagnose detrusor underactivity in a group of LUTS patients with different $\mathrm{BOO}$ grades.

Chapter 3 describes the development of a pressure-flow based, BOO related, bladder contractility nomogram in men with LUTS, the Maastricht-Hannover nomogram. The nomogram quantifies the relationship between detrusor contractility and BOO in men with LUTS by the use of $\mathrm{W}_{\max }$ (as contractility parameter) and bladder outlet obstruction index (BOOI, as obstruction parameter). Our results show that a measurement value $<25^{\text {th }}$ percentile correlates with clinical indicators of DU (higher age, higher bladder capacity, larger post-void residual volume and lower voiding efficiency and is proposed as a cut-off value for DU-diagnosis.

Chapter 4 is a first clinical validation study of the Maastricht-Hannover nomogram. Purpose of the study was to assess whether the use of the new BOO-contractility (Maastricht-Hannover) nomogram can identify and predict SNM non-responders. For the first time, SNM treatment response in male patients with impaired bladder emptying can 
be predicted with the BOO-contractility (Maastricht-Hannover) nomogram. Men below the $10^{\text {th }}$ percentile are likely to be treatment non-responders, whereas the majority of men above the $10^{\text {th }}$ percentile are responders.

Chapter 5 focuses on non-invasive diagnostic techniques to assess detrusor underactivity. Pressure-flow studies are expensive, time consuming and may cause complications. Therefore, a non-invasive assessment may be valuable in the workup of male patients with voiding dysfunction and a suspicion of DU. Classification And Regression Tree (CART) analysis shows that ultrasound detrusor wall thickness (DWT $\leq 1.23 \mathrm{~mm}$ ) combined with relatively high bladder capacity ( $>445 \mathrm{ml}$ ) may predict DU in males with LUTS. The combination of these two tests could help physicians to diagnose DU noninvasively in clinical practice.

Chapter 6 is a think tank panel publication by the International Consultation on Incontinence (ICl-RS). In the past there has not been an extensive focus on the terms 'BOO' and 'bladder contractility' in women. At present, only limited women-specific BOO and bladder contractility indices are available. Therefore, the ICI-RS panel has put forward the following recommendations: the need to acquire normative age matched data in women to define "normal" and "pathological" values of urodynamic parameters; the inclusion of additional clinical data in new nomograms and the use of this extra dimension to develop clinically applicable nomograms for female BOO and contractility; and finally, the need to take into account the variability of $\mathrm{BOO}$ in women when developing female bladder contractility nomograms.

Chapter 7 gives an overview of the available evidence for a surgical treatment modality in patients with bladder acontractility. The history, anatomy, technique, results and complications of the latissimus dorsi detrusor myoplasty (LDDM) are described. LDDM outcome across the various studies ranges between 70.8 and $85.0 \%$ complete response (meaning PVR<100 ml). However, the current literature only gives limited information about the long-term effects of LDDM treatment.

Chapter 8 is a second think tank panel publication by the International Consultation on Incontinence (ICl-RS) on the pathophysiological background of DU and proposals for future research. The recommendations made by the ICI-RS panel include: Development of study tools based on a system's pathophysiological approach, correlation of in vitro and in vivo data in experimental animals and humans, and development of more comprehensive translational animal models. In addition, there is a need for longitudinal patient data to define risk groups and for the development of screening tools.

In summary, research with regard to DU and impaired bladder emptying in men and women has received increasing attention in recent years. However, only limited new data on pathophysiology, assessment of contractile function and treatment targets have been published. This thesis is the first of its kind, focussing on new developments in the assessment of DU and giving recommendations for (near-)future research opportunities. 




\section{Nederlandse Samenvatting (Dutch Summary)}

Symptomen passend bij incomplete blaaslediging kunnen worden veroorzaakt door een te weinig actieve blaasspier (detrusor): ook wel genoemd Detrusor onderactiviteit (DU), blaas uitgangs obstructie (BOO) of beiden en zijn frequent een reden voor bezoek aan de polikliniek urologie. Detrusor onderactiviteit (DU) is een functioneel urologische entiteit welke vaak verscholen is achter andere oorzaken van blaasledigingsdisfunctie en waarvoor er geen consensus is met betrekking tot diagnostische evaluatie of behandeling. Gedurende lange tijd is er echter nauwelijks tot geen aandacht geweest voor het onderscheid tussen deze entiteiten, DU en BOO, gerelateerd aan de symptomatologie. Pas vanaf de International Consultation on Incontinence research society (ICl-RS) bijeenkomst in 2011 heeft onderzoek op dit gebied een nieuwe impuls gekregen. De inhoud van deze thesis heeft de aanzet gegeven tot verder onderzoek op het gebied van DU, met specifieke aandacht voor de pathofysiologie van de ledigingsfunctie van de blaas, technieken om DU te vast te stellen en te kwantificeren, en therapeutische opties en kaders voor DU.

Hoofdstuk 1 bespreekt de rol van alternatieve urodynamica methoden en instrumenten om verschillende disfuncties van de lagere urinewegen (LUTS) te onderscheiden. In dit hoofdstuk is er specifieke aandacht voor het gebruik van ambulante urodynamica (AUM) bij blaasledigingsproblematiek. Bij standaard urodynamica wordt de blaas artificieel gevuld via een katheter en wordt de (blaas)druk geregistreerd tijdens de vul- en ledigingsfase van de blaas. AUM is een meerdere uren durende meting van o.a. de blaasdruk in een alledaagse situatie waarbij de blaas zich ook op de natuurlijke manier vult. De contractiele disfunctie van de detrusor spier die kan worden vastgesteld middels AUM kan variëren van DU/hypocontractiliteit tot een volledig acontractiele blaas. Resultaten van deze studie laten zien dat AUM beter is in het onderscheiden van patiënten met blaas acontractiliteit en hypocontractiliteit dan conventionele blaasdrukmeting. Deze kennis is nodig bij de behandeling van DU patiënten, bijvoorbeeld bij patiënten die behandeld worden met sacrale neuromodulatie (SNM). Patiënten met op AUM gebaseerde acontractiliteit van de blaas hebben minder kans op een succesvolle SNM behandeling vergeleken met patiënten met op AUM gebaseerde hypocontractiliteit.

Hoofdstuk 2 is het eerste in een drieluik van publicaties waarin de aandacht is gevestigd op de relatie tussen $\mathrm{BOO}$ en de contractiele functie van de detrusor spier bij mannen tijdens de mictie. In de urologische praktijk worden zowel de bladder contractility index $(\mathrm{BCl})$ als maximum Watts factor $\left(\mathrm{W}_{\max }\right)$ gebruikt om detrusor kracht bij mannen met LUTS te kwantificeren. Hierbij worden vaste afkapwaarden gebruikt voor alle mannen. Deze retrospectieve cohort studie laat zien dat deze detrusor contractiekracht parameters - $\mathrm{BCl}$ en $\mathrm{W}_{\text {max }}$ - continu toe nemen bij een stijgende obstructie graad. Deze resultaten laten zien dat het onmogelijk is om middels één enkele afkapwaarde voor detrusor contractiekracht de detrusor onderactiviteit te kwantificeren bij mannelijke LUTS patiënten met verschillende BOO gradaties. Er moet dus worden gezocht naar alternatieve meetmethodes om bij de verdenking op DU, de contractiekracht van de detrusor spier te kwantificeren. 
Hoofdstuk 3 beschrijft de ontwikkeling van een op urodynamica gebaseerd nomogram waarin blaas contractiliteit wordt uitgezet tegen BOO bij mannen met LUTS, het zogenaamde Maastricht-Hannover nomogram. Het nomogram kwantificeert de relatie tussen detrusor contractiliteit en BOO bij mannen met LUTS door gebruik van $\mathrm{W}_{\max }$ (als contractiliteitsparameter) en bladder outlet obstruction index (BOOI, als obstructie

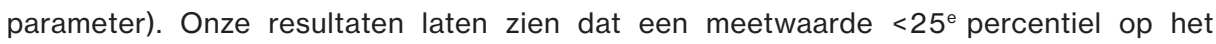
nomogram correleert met klinische indicatoren van DU (hogere leeftijd, grotere blaas capaciteit, groter residuaal volume na mictie en lagere mictie efficiëntie. Derhalve wordt deze afkapwaarde voorgesteld om DU te diagnosticeren.

Hoofdstuk 4 is een eerste klinische validatie studie van het Maastricht-Hannover nomogram. Het doel van de studie was om te kijken of dit nieuwe BOO-contractiliteits (Maastricht-Hannover) nomogram gebruikt kan worden om het falen van een behandeling met SNM vast te stellen en te voorspellen. Voor het eerst kan nu de SNM behandelingsrespons bij mannen met incomplete blaaslediging worden voorspeld door het gebruik van het Maastricht-Hannover nomogram. Van de mannen onder het $10^{\mathrm{e}}$ percentiel op het nomogram reageert slechts $20 \%$ op behandeling met SNM. In tegenstelling tot de groep boven het $10^{\mathrm{e}}$ percentiel, waarvan het grootste deel van de mannen respondeert op behandeling met SNM.

Hoofdstuk 5 richt zich op niet-invasieve diagnostische technieken om DU te identificeren. Urodynamica is een dure, invasieve methode welke tijdrovend is en mogelijk leidt tot complicaties van de interventie. Om deze redenen zou een niet-invasieve techniek van waarde kunnen zijn in de analyse van mannelijke patiënten met een blaasledigingsstoornis en de verdenking op DU. Een classificatie en regressie analyse (genaamd CART) laat zien dat echografische weergave van de detrusor wanddikte (DWT $\leq 1.23 \mathrm{~mm}$ ) gecombineerd met een relatief grote blaascapaciteit ( $>445 \mathrm{ml}$ ) mogelijk voorspellend is voor DU bij mannen met LUTS. De combinatie van deze twee technieken kan clinici helpen om DU op een nietinvasieve manier, door gebruik van een echo, vast te stellen in de dagelijkse praktijk.

Hoofdstuk 6 is een denktank panel publicatie door de International Consultation on Incontinence (ICl-RS). In het verleden is er weinig onderzoeksinteresse geweest voor de termen 'BOO' en 'blaascontractiliteit' bij vrouwen. Dit heeft tot gevolg dat momenteel slechts enkele, voor vrouwen specifieke, BOO en blaascontractiliteit parameters beschikbaar zijn. Derhalve heeft het ICI-RS panel de volgende aanbevelingen gegeven: de noodzaak van normatieve, met leeftijd geassocieerde data voor vrouwen om te bepalen welke urodynamica waarden als 'normaal' en 'pathologisch' worden gezien; de toevoeging van additionele klinische data aan nieuwe nomogrammen en het gebruik van deze klinische informatie moeten zorgen voor klinisch toepasbare nomogrammen voor BOO en contractiliteit bij vrouwen. Tot slot moet de variabiliteit van $\mathrm{BOO}$, door het wisselend aanspannen van de bekkenbodemspieren, bij vrouwen in acht worden genomen wanneer dergelijke blaascontractiliteit nomogrammen worden ontwikkeld. 
Hoofdstuk 7 geeft een overzicht van de beschikbare literatuur met betrekking tot de chirurgische behandeling van patiënten met blaas acontractiliteit. De geschiedenis, anatomie, techniek, resultaten en complicaties van de latissimus dorsi detrusor myoplastiek (LDDM) worden beschreven in deze publicatie. LDDM is een procedure waarbij een spierflap (latissimus dorsi spier) om de blaas wordt gewikkeld als alternatief voor de niet goed functionerende blaasspier. De LDDM resultaten in de verschillende studies variëren in een complete behandelingsrespons (dit betekent een residuaal volume na mictie $<100 \mathrm{ml}$ ) tussen 70.8 en $85.0 \%$. Echter, de huidige literatuur geeft slechts weinig inzicht in de langetermijneffecten van behandeling middels LDDM bij patiënten met blaas acontractiliteit.

Hoofdstuk 8 is een tweede denktank panel publicatie door de International Consultation on Incontinence (ICl-RS) met betrekking tot de pathofysiologische achtergrond van DU en voorstellen voor toekomstig onderzoek op dit gebied. Aanbevelingen door het ICI-RS panel luiden als volgt: ontwikkeling van studie technieken gebaseerd op de pathofysiologische benadering van een system; correlatie van in vitro en in vivo data bij proefdieren en mensen; en de ontwikkeling van diermodellen die te vertalen zijn naar de menselijke situatie. Additioneel aan deze aanbevelingen is er de noodzaak tot longitudinale verzameling van patiënten data om zo risicogroepen te definiëren en hiermee screeningstechnieken te ontwikkelen.

Samenvattend is er sinds enkele jaren een evidente toename in onderzoek met betrekking tot het onderwerp DU en blaasledigingsproblematiek bij zowel mannen als vrouwen. Er is echter nog weinig bewijskracht voor de pathofysiologische mechanismen, het meten van contractiele functie en behandelstrategieën bij DU. Dit proefschrift is het eerste proefschrift dat zich richt op dit onderwerp binnen de functionele urologie en waarin de aandacht is gevestigd op nieuwe ontwikkelingen in de diagnostiek van DU en aanbevelingen worden gegeven voor toekomstige onderzoeksmogelijkheden. 